\title{
Review \\ Use of Circulating Tumour DNA (ctDNA) for Measurement of Therapy Predictive Biomarkers in Patients with Cancer
}

\author{
Michael J. Duffy ${ }^{1,2, *(\mathbb{D})}$ and John Crown ${ }^{3}$ \\ 1 UCD School of Medicine, Conway Institute of Biomolecular and Biomedical Research, \\ University College Dublin, D04 V1W Dublin, Ireland \\ 2 UCD Clinical Research Centre, St. Vincent's University Hospital, D04 T6F4 Dublin, Ireland \\ 3 Department of Medical Oncology, St Vincent's University Hospital, D04 T6F4 Dublin, Ireland; \\ John.Crown@ccrt.ie \\ * Correspondence: MICHAEL.J.DUFFY@UCD.IE; Tel.: +353-1-7165814; Fax: +353-1-2696018
}

Citation: Duffy, M.J.; Crown, J. Use of Circulating Tumour DNA (ctDNA)

for Measurement of Therapy

Predictive Biomarkers in Patients

with Cancer. J. Pers. Med. 2022, 12, 99.

https://doi.org/10.3390/jpm12010099

Academic Editor: Caroline Heckman

Received: 8 December 2021

Accepted: 30 December 2021

Published: 13 January 2022

Publisher's Note: MDPI stays neutral with regard to jurisdictional claims in published maps and institutional affiliations.

Copyright: (C) 2022 by the authors. Licensee MDPI, Basel, Switzerland. This article is an open access article distributed under the terms and conditions of the Creative Commons Attribution (CC BY) license (https:// creativecommons.org/licenses/by/ $4.0 /)$.

\begin{abstract}
Biomarkers that predict likely response or resistance to specific therapies are critical in personalising treatment for cancer patients. Such biomarkers are now available for an increasing number of anti-cancer therapies, especially targeted therapy and immunotherapy. The gold-standard method for determining predictive biomarkers requires tumour tissue. Obtaining tissue, however, is not always possible and even if possible, the amount or quality of tissue obtained may be inadequate for biomarker analysis. Tumour DNA, however, can be released into the bloodstream, giving rise to what is referred to as circulating tumour DNA (ctDNA). In contrast to tissue, blood can be obtained from effectively all patients in a minimally invasive and safe manner. Other advantages of blood over tissue for biomarker testing include a shorter turn-around time and an ability to perform serial measurements. Furthermore, blood should provide a more complete profile of mutations present in heterogeneous tumours than a single-needle tissue biopsy. A limitation of blood vis-à-vis tissue, however, is lower sensitivity and, thus, the possibility of missing an actionable mutation. Despite this limitation, blood-based predictive biomarkers, such as mutant EGFR for predicting response to EGFR tyrosine kinase inhibitors in advanced non-small-cell lung cancer and mutant PIK3CA for predicting response to alpelisib in combination with fulvestrant in advanced breast cancer, may be used when tissue is unavailable. Although tissue remains the gold standard for detecting predictive biomarkers, it is likely that several further blood-based assays will soon be validated and used when tissue is unavailable or unsuitable for analysis.
\end{abstract}

Keywords: biomarker; predictive; companion diagnostic; ctDNA; liquid biopsy; cancer

\section{Introduction}

Circulating tumour DNA (ctDNA), i.e., DNA shed by malignant cells into the circulation, is emerging as potentially one of the most transformative biomarkers in oncology [1-3]. Indeed, preliminary results suggest that measurement of ctDNA may be useful in screening for early cancer, detecting micrometastasis (minimum residual disease) following curativeintent surgery, upfront selecting appropriate systemic treatment and monitoring response to ongoing therapy in advanced disease [1-3]. Although its role in most of these setting is still largely exploratory, ctDNA measurement has already entered clinical use for systemic therapy selection.

Rationally, selecting treatment is aided by biomarkers known as predictive or response biomarkers. Such tests upfront identify patients that are likely to be responsive or resistant to a specific treatment. A related type of biomarker, known as a companion diagnostic, is defined by US Food and Drug Administration (FDA) as a medical device that provides information that is essential for the safe and effective use of a corresponding drug or biological product. 
Predictive biomarkers/companion diagnostics are important in therapy decision making as they help to identify patients that are likely to benefit from a specific therapy. Consequently, such patients can then be treated with a relevant therapy with a high probability of success. At the same time, these biomarkers can spare patients who are unlikely to be responsive, from unnecessary drug toxicity and costs. In some situations, these patients may be able to receive a different effective therapy, thus saving time and money. Alternatively, such patients may be able to participate in an appropriate clinical trial. Overall, the availability of predictive biomarkers/companion diagnostics is leading to a more rational, cost-effective and personalised use of anti-cancer therapies. Importantly, in an increasing number of situations, performance of these tests when followed by administration of the appropriate matching therapy is resulting in better response rates, improved outcome and less therapy-induced toxicity than was traditionally available [4-12].

\section{Current Strategies for Measurements of Predictive Biomarkers/Companion Diagnostics}

Predictive biomarkers / companion diagnostics are currently available for a broad range of systemic therapies, especially targeted therapies and immunotherapy with immune check point inhibitors (Table 1) [13-16]. Indeed, the vast majority of new therapies currently entering clinical use has an associated predictive biomarker/companion diagnostic. The gold standard methodology for measuring predictive biomarkers/companion diagnostics requires tumour tissue. Acquiring tissue, however, necessitates an invasive procedure, such as surgery or biopsy, which is inconvenient for patients and in some situations may cause harm. Indeed, in some elderly or frail patients, a biopsy may not be possible and even if possible, it may not yield a sufficient amounts of suitable tissue for biomarker analysis [17-19]. Obtaining tissue may be especially difficult in patients with advanced progressing therapy-resistant cancers or in patients with certain sites of metastases (e.g., brain). Thus, in one report, a biopsy could not be performed in $50 \%$ of the patients with non-small-cell lung cancer (NSCLC) who developed resistance to first-line EGFR tyrosine kinase inhibitors (TKI) [18]. Even if tissue is accessed, it may not be sufficient or suitable for measuring the multiple biomarkers currently recommended for specific cancers such as NSCLC. Indeed, in some reports less than $20 \%$ of biopsies were found to have adequate tissue for detecting all the recommended genomic tests in patients with NSCLC [20].

A further potential problem with tissue is molecular intra- and inter-tumour heterogeneity. DNA sequencing using multi-locational sampling has shown that malignant tissue is composed of highly heterogeneous cell populations as regards to somatic mutations [21]. Single biopsies whether from a primary or metastatic tumour may thus not be representative of the whole tumour load but rather indicative of genomic state at a single time point and at a single location. Heterogeneity is likely to be most prevalent in patients with rapidly evolving tumours, multi-focal tumours or multiple metastases and in those previously treated who develop acquired resistance to the therapy. Indeed, in the setting of acquired therapy resistance, the emergence of multiple resistance mechanisms appears to be widespread [22]. Clearly, in such a situation, a single biopsy may miss potentially actionable mutations. Other limitations of tissue for analysis of predictive biomarker companion diagnostics are listed in Table 2. 
Table 1. Examples of predictive biomarkers/companion diagnostics for therapy decision making in patients with different advanced cancers.

\begin{tabular}{|c|c|c|c|c|}
\hline Biomarker & Alteration & Therapy & Cancer(s) & LOE \\
\hline $\mathrm{ER} / \mathrm{PR}$ & Overexpression & Endocrine & Breast & NS \\
\hline HER2 & Amplification/overexpression & Anti-HER2 & Breast & 1 \\
\hline HER2 & Amplification/overexpression & Anti-HER2 & Gastric & 1 \\
\hline EGFR & Mutation (ex 19 del, L858R) & EGFR TKIs & NSCLC & 1 \\
\hline PIK3CA & Mutation & Alpelisib & Breast & 1 \\
\hline KRAS/NRAS * & Mutation & Cetuximab, panitumumab & CRC & 1 \\
\hline BRCA1/2 & Mutation ** & Olaparib, rucaparib & Prostate (castrate resistant) & 1 \\
\hline BRCA1/2 & Mutation & Rucaparib & Ovarian & 1 \\
\hline $\mathrm{BRCA} 1 / 2$ & Mutation ** & Olaparib, talazoparib & Breast & 2 \\
\hline ATM & Mutation & Olaparib & Prostate (castrate resistant) & 1 \\
\hline ALK & Translocation & Alectinib & NSCLC & 1 \\
\hline HER2 * & Mutation & Neratinib & Breast & 3 \\
\hline $\mathrm{AKT} *$ & Mutation & Capivasertib & Breast & 3 \\
\hline NTRK1/2/3 & Fusion & Entrectinib, Larotrectinib & All solid tumours & 1 \\
\hline FGFR2/3 & Fusion & Erdafitinib & Bladder & 1 \\
\hline FGFR2 & Fusion & Cholangiocarcinoma & Pemigatinib & 1 \\
\hline RET & Fusion & NSCLC & Pralsetinib, Selpercatinib & 1 \\
\hline RET & Fusion & Thyroid & Pralsetinib, Selpercatinib & 1 \\
\hline MSI-H ${ }^{*}, \mathrm{TMB}^{*}$ & & $\begin{array}{c}\text { Immune checkpoint } \\
\text { inhibitors }\end{array}$ & Multiple & 1 \\
\hline
\end{tabular}

LOE, level of evidence as specified in OncoKB list of actionable genes. ER/PR, oestrogen and progesterone receptors; NS, not stated (but should be LOE 1): NSCLC, non-small-cell lung cancer; CRC, colorectal cancer; $\mathrm{CR}$, castrate resistant; MSI-H, microsatellite instability high; ICI, immune checkpoint inhibitors. ${ }^{*}$ Tests do not have an US FDA approved assay, ** germline mutation. Data summarised from references [13-16] and https://www.oncokb.org/actionableGenes (accessed on 14 June 2021). List of predictive biomarkers/companion diagnostics is not meant to be comprehensive.

Table 2. Limitations of tissue and corresponding advantages of ctDNA for detecting predictive biomarkers/companion diagnostics.

\begin{tabular}{ccc}
\hline Limitations of Tissue & Advantages of ctDNA & Reference(s) \\
\hline Inconvenient for patients & More convenient and acceptable & \\
\hline $\begin{array}{c}\text { Invasive and risky } \\
\text { Access may not be possible in } \\
\text { some patients }\end{array}$ & Minimally invasive and little risk & \\
\hline $\begin{array}{c}\text { May not fully capture } \\
\text { tumour heterogeneity }\end{array}$ & $\begin{array}{c}\text { More likely to capture tumour } \\
\text { heterogeneity especially with } \\
\text { acquired resistance }\end{array}$ & {$[22]$} \\
\hline $\begin{array}{c}\text { Can miss some actionable mutations } \\
\text { due to tumour heterogeneity }\end{array}$ & $\begin{array}{c}\text { More actionable } \\
\text { mutations detected }\end{array}$ & {$[23-26]$} \\
\hline Relatively long turn-around-time & $\begin{array}{c}\text { Shorter turn-around-time } \\
\text { Difficult to repeat or perform } \\
\text { serial assays }\end{array}$ & $\begin{array}{c}\text { Minimal problem in performing } \\
\text { serial assays }\end{array}$ \\
\hline Relatively expensive & Less expensive & {$[26,29]$} \\
\hline
\end{tabular}




\section{Advantages of Blood over Tissue for Measuring Predictive Biomarkers/Companion Diagnostics}

Many of the limitations of tissue for biomarker testing can be circumvented by measuring DNA shed from tumours into blood (Table 2). Use of circulating ctDNA (also known as liquid biopsy) is thus an attractive alternative source of tumour DNA, when surgery/biopsy cannot be performed or when the tissue obtained is insufficient or unsuitable for analysis [1-3]. Furthermore, use of ctDNA might be expected to give a broader overview of mutations present at different tumour locations than a single-needle biopsy, thus potentially detecting more actionable mutations [22,23]. Indeed, across different tumour types, use of ctDNA has resulted in the detection of more potentially actionable genes than tissue [23-26]. Other key advantages of ctDNA over tissue testing include faster turn-around time for reporting of result [26,27], less costly to perform [28,29] and ease of performing serial measurements. The latter may be particularly useful in monitoring the effectiveness of ongoing treatments, identifying the early emergence of resistance and identifying the mechanism of resistance, see below.

These advantages of blood over tissue have led in recent years to the intensive investigation of ctDNA for the measurement of predictive biomarker/companion diagnostic, for a range of therapeutics across different cancer types. Indeed, several therapeutics currently have approved ctDNA-based assays for guiding their use (see below). The clinical utility of these approved ctDNA assays is discussed below. In addition, we also discuss emerging plasma-based predictive biomarkers/companion diagnostics.

\section{Mutant EGFR for Predicting Response to EGFR TKIs in Patients with Non-Small-Cell Lung Cancer}

The first ctDNA predictive biomarker/companion diagnostic to enter clinical use involved mutational analysis of EGFR for the identification of patients with NSCLC that were likely to benefit from EGFR tyrosine kinase inhibitors (TKIs) [30-32]. Activating (also known as sensitising) mutations somatic EGFR mutations are present in 15-25\% of Caucasian subjects and in 35-50\% of East-Asian patients with untreated NSCLC [30-32]. Approximately $90 \%$ of these mutations involve an in-frame deletion in exon 19 (codons 746-750) or an L858R point mutation in exon 21. Less frequent mutations include G719X (4\%), L861X (1\%), S768I (1\%) mutations, and exon 20 insertions (2\%). These mutations, especially the in-frame deletion in exon 19 and L858R, alter the structure of the ATP binding pocket in the tyrosine kinase domain of EGFR, leading to ligand-independent activation. This in turn results in increased RAS-RAF-MAPK signalling, which ultimately drives the growth and progression of NSCLC.

Since mutant EGFR is a driver gene for a subset of NSCLC, several TKI were developed to target the corresponding mutant protein. Currently, at least five clinically approved (US FDA) EGFR TKI are available, gefitinib, erlotinib (first generation), afatinib and dacominitib (second generation) and osimertinib (third generation) [32]. Gefitinib, erlotinib and afatinib are selective for EGFR sensitising mutation such as the in-frame deletion in exon 19 or L858R point mutations in exon 21, while osimertinib is selective for both the sensitising mutations and T790M resistance mutation (see below). Since these compounds possess higher affinity than the natural kinase substrate, ATP for the ATP-binding pocket in EGFR, they competitively inhibit the tyrosine kinase activity of the mutant receptor, thus blocking downstream signalling which in turn leads to inhibition of tumour cell growth.

Several randomised phase III trials have now shown that treatment of NSCLC patients with advanced disease possessing sensitising EGFR mutations using first- or secondgeneration TKIs resulted in superior response rates, enhanced progression-free survival, reduced toxicities and increased quality of life compared to standard chemotherapy (for review, see references [30-33]). Recently, the third generation TKI inhibitor, osimertinib was shown to enhance overall survival compared with gefitinib or erlotinib (hazard ratio (HR) for death, $0.80 ; 95.0 \%$ CI, 0.64 to 1.00; $p=0.046$ ) [34]. Based on this finding, joint guidelines recently published by the American Society of Clinical Oncology (ASCO) and 
Ontario Health $(\mathrm{OH})$ stated that where available, osimertinib should be the optimal first-line treatment for NSCLC patients with sensitising EGFR mutations [35].

Based on the early clinical results with first generation TKIs, tissue mutation analysis of EGFR entered clinical use for selecting patients with metastatic NSCLC likely to benefit from these drugs. However, as mentioned above, the use of tissue has several limitations, many of which can be largely overcome by analysing ctDNA. Overall, strong concordance (70-90\%) is found between the presence of EGFR activating mutations in tumour tissue and matching ctDNA [36-40]. Thus, following a meta-analysis of 27 studies involving $>4000$ patients, the pooled sensitivity, specificity and areas under the curve for ctDNA versus tissue were $60 \%, 94 \%$, and 0.9208 for the detection of EGFR mutations. For detecting exon 19 deletions, the corresponding values were $64 \%, 99 \%$, and 0.9583 and for detecting L858R mutations, values were $57 \%, 99 \%$, and 0.9605 , respectively [36]. In a more recent prospective study involving 180 patients with advanced NSCLC, ctDNA had a specificity of $100 \%$ for both EGFR 19 del and L858R mutation [37]. The sensitivity of ctDNA however, was $82 \%$ for EGFR $19 \mathrm{del}$ and $74 \%$ for L858R. For a commercial EGFR ctDNA mutation assay approved by both the European Medicines Agency (EMA) and the US Food and Drug Administration (FDA), i.e., Cobas (Roche Molecular Systems) (see below), the ctDNA assay exhibited a specificity of $98.2 \%$ and a sensitivity of $76.7 \%$ for the detection of both the EGFR exon 19del and L858R mutations [38]. These latter results were achieved with patients participating in a randomised phase III trial (ENSURE) which compared the efficacy and safety of erlotinib with gemcitabine + cis-platin in patients with advanced NSCLC [39].

Clearly, ctDNA provides high specificity for detecting EGFR activating mutations across multiple different studies. Sensitivity of ctDNA assays however, is less good. Despite this lower sensitivity using ctDNA, both assays have been reported to have similar predictive value for evaluating response to EGFR TKIs [40-42].

The high specificity of ctDNA for detecting tumour EGFR mutations provides confidence that a positive ctDNA test could be used in selecting NSCLC patients for treatment with EGFR TKIs. However, because of the relatively low sensitivity (70-80\%), absence of a plasma mutation does not necessary exclude the presence of a mutation in the corresponding tumour specimen. In such a situation, tissue should be evaluated when feasible. Based on its high specificity [37-40], minimally invasive approach as well as a faster turn-aroundtime for reporting $[27,28]$, several expert panels currently recommend that for patients with advanced NSCLC where tissue cannot be obtained or is insufficient for mutation testing, ctDNA may be used to identify EGFR mutations [43-46]. The guidelines, however, also add that because the sensitivity of ctDNA assays is lower than that of tissue, a negative result from a ctDNA test should not be interpreted that the corresponding tumour is also EGFR mutation-negative [43-46]. As mentioned above, in such a situation, tissue testing should be performed where possible.

Several different research and commercial assays are available for detecting EGFR mutation in ctDNA, including real-time/quantitative PCR, digital droplet (dd) PCR, BEAMing PCR and next generation sequencing (NGS) (for detailed review, see reference [46]). Importantly, from a clinical point of view, some of the commercially available assays have received regulatory approval in different parts of the world. One of the first to receive such approval was the cobas EGFR Mutation Test v2. This real-time PCR assay which is approved by both the EMA and the US FDA, detects 42 mutations in exons 18-21 of the EGFR gene, including L858R, exon 19 deletions, L861Q and T790M. Another PCR test, i.e., the therascreen EGFR Plasma RGQ PCR Kit (Qiagen), has received the Conformité Européenne (CE) mark for use in Europe. This assay detects deletions in exon 19, the T790M mutation in exon 20 and the L858R mutation in exon 21 of the EGFR gene.

While PCR is suitable for detecting single/low number of mutations, it is not appropriate for analysing the full panel of biomarkers currently recommended for patients with NSCLC. Thus, the 2021 guidelines recently published by the International Association for the Study of Lung Cancer (IASLC) state "because of the growing number of guideline-recommended oncogene targets to be assessed in advanced NSCLC, testing of 
plasma ctDNA should be performed by a clinically validated NGS platform rather than single-gene, PCR-based approaches, both in treatment-naive patients and those associated with multiple mechanisms of acquired resistance to targeted agents". However, the group also added that if NGS is not available, single-gene analysis by PCR may be used. Next generation sequencing tests approved by the US FDA for predicting response to EGFR TKIs in NSCLC include the Guardant360 CDx and the FoundationOne Liquid CDx, assays [46].

\section{T790M Mutant EGFR for Predicting Acquired Resistance to First Generation EGFR TKIs in Patients with Non-Small-Cell Lung Cancer}

While EGFR sensitising mutations such as L858R and exon 19 deletions are associated with benefit from EGFR TKIs in patients with NSCLC, acquired resistance at least to gefitinib and erlotinib occurs with the emergence of the T790M mutation. This secondary mutation which is found in 50 to $60 \%$ of resistant cases [47] is believed to cause resistance by increasing the affinity of EGFR for its physiological substrate, ATP, thus sterically blocking the binding of first generation TKIs [47]. Most patients with this mutation, however, respond to the third generation EGFR TKI, osimertinib [47].

As with the more commonly occurring EGFR activating mutations, the EGFR T790M resistance mutation can also be detected using ctDNA. Overall, the concordance between tissue and ctDNA for the T790M mutation is less good that is found with the exon 19 deletions and L858R mutations [47-50]. Thus, following a systematic review of 21 studies involving 1639 patients, the pooled sensitivity of ctDNA versus tissue was $67 \%$, the pooled specificity was $80 \%$ while the pooled positive predictive value (PPV) was $85 \%$ and the pooled negative predictive value (NPV) was 60\% [50]. The lower predictive accuracy of ctDNA is possibly due to the T790M mutation being an acquired mutation and as a result is subclonal and present at lower abundance than the activating driver mutations.

Despite this less than ideal concordance, response rates to osimertinib in patients positive for the ctDNA T790M mutations appear to be similar to those positive using a tissue biopsy [48-51]. Thus, as with the L858R mutation and exon 19 deletions, several expert panels currently state that ctDNA may be used to identify EGFR T790M mutations for predicting response to osimertinib in patients with advanced NSCLC who develop acquired resistance to first generation EGFR-TKIs [43-46]. Again, the guidelines add that testing of tumour tissue if feasible is recommended, if the ctDNA result is negative. Going further, the IASLC state that when acquired resistance to TKI occurs, "initial use of ctDNA is preferred for evaluating mechanisms of resistance, with repeat biopsy if ctDNA is uninformative" [46].

\section{EGFR Exon 20 Insertions for Predicting Response to Amivantamab-Vmjw or Mobocertinib}

Two to 3\% of NSCLC patients possess an EGFR exon 20 insertion which confers resistance to the currently approved EGFR TKIs [51]. Patients with this mutation, however, were recently reported to respond to amivantamab-vmjw (a bispecific antibody that targets both EGFR and MET) [52] or mobocertinib (a tyrosine kinase inhibitor) [53]. Subsequently, both these therapies were approved by the US FDA for the treatment of NSCLC patients with an EGFR exon 20 insertion. Simultaneously with the approval of amivantamabvmjw, the US FDA also approved a companion diagnostic (Guardant360 CDx) that may be measured using ctDNA to identify patients with EGFR exon 20 insertions.

\section{Mutant PIK3CA for Predicting Response to Alpelisib in Patients with Advanced Breast Cancer}

Another approved ctDNA test for predicting response to a specific therapy involves mutation analysis of PIK3CA for identifying patients with advanced breast cancer likely to benefit from treatment with the $\alpha$-specific PIK3CA inhibitor, alpelisib (in combination with the oestrogen receptor degrading compound, fulvestrant) [54].

The PIK3CA gene, which codes for the catalytic subunit of the PI3K signalling protein, is the most frequently mutated oncogene in breast cancer, with mutations present in 35-40\% 
of samples [55,56]. Most of the PIK3CA mutations occur at one of three hotspots, i.e., at E545K and E542K in exon 9 within the helical domain and at H1047 in exon 20 within the kinase domain. Although the vast majority of mutations in PIK3CA are single mutations, $12-15 \%$ of breast cancers have multiple mutations in the gene [57]. The presence of multiple cis mutations has been reported to increase oncogenicity [57].

Analogous to the situation with mutant EGFR in patients with NSCLC, a strong correlation has been found between the presence of PIK3CA mutations in breast tumour tissue and corresponding ctDNA. For example, a meta-analysis of 7 cohorts from 5 studies involving 247 patients, concluded that the pooled sensitivity and specificity of ctDNA for detecting tissue PIK3CA mutations were $86 \%$ and $98 \%$, respectively [58]. In 2019, the US FDA approved the administration of alpelisib in combination with fulvestrant for the treatment of metastatic breast cancer patients with hormone receptor-positive, HER2negative breast cancer possessing PIK3CA-mutations, following disease progression on or after endocrine therapy [54]. This approval was based on findings from a randomised phase III trial (SOLAR-I trial) which compared treatment with alpelisib plus fulvestrant versus treatment with fulvestrant alone in patients with hormone receptor-positive, HER2-negative patients that had previously progressed on endocrine therapy [59]. The trial showed that alpelisib in combination with fulvestrant almost doubled the median progression-free survival compared with fulvestrant alone (median progression free survival, 11.0 months versus 5.7 months; $\mathrm{HR}=0.65,95 \% \mathrm{CI}$ : 0.50-0.85; $p<0.001$ ) in patients with PIK3CA mutations (detected in tissue or plasma) but had no benefit in those lacking such mutations. In addition to progression-free survival, overall response rates were also significantly increased when alpelisib was combined with fulvestrant in patients with PIK3CA mutations (35.7\% for the combination versus $16.2 \%$ for fulvestrant alone; $p=0.0002$ ). This extended overall survival was confirmed in a recent update report which showed an 8-month improvement in median overall survival with alpelisib plus fulvestrant versus fulverstrant monotherapy in patients with PIK3CA-mutated tumours (although the findings did not cross the pre-specified boundary for statistical significance) [60].

Simultaneously with the approval of alpelisib + fulvestrant for advanced breast cancer treatment, the US FDA also approved a companion diagnostic test, i.e., therascreen PIK3CA RGQ PCR Kit, for detecting PIK3CA mutation in tissue and/or ctDNA. This assay detects 11 PIK3CA hotspot mutations, i.e., exon 7: C420R; exon 9: E542K, E545A, E545D [1635G > T only], E545G, E545K, Q546E, Q546R; and exon 20: H1047L, H1047R, H1047Y. (Available online: https: / / www.accessdata.fda.gov/cdrh_docs/pdf19/P190001A.pdf, accessed on 1 November 2021). According to the FDA approval statement, breast cancer patients with tissue or plasma-positive therascreen PIK3CA RGQ PCR Kit test result are eligible for treatment with alpelisib. However, in patients with plasma-negative results, reflexing to tumour tissue testing for the presence of PIK3CA mutations should be performed if possible. More recently, the Foundation Medicine's FoundationOne CDx (F1CDx) assay also received US FDA approval for predicting benefit from alpelisib in breast cancer. This test detects the same 11 mutations as the QIAGEN assay mentioned above.

In addition to alpelisib, the ability of circulating mutant PIK3CA to predict response to other PIK3CA inhibitors has also been investigated. In the SANDPIPER phase III clinical trial which compared the efficacy of the $\alpha, \gamma$ and $\delta$ PIK3CA inhibitor, taselisib in combination with fulvestrant, versus a placebo + fulvestrant, the presence of PIK3CA mutations also predicted an enhanced response to the PI3KCA inhibitor-based treatment, i.e., HR for progression free survival for patient with PIK3CA-mutant-positive was 0.86 (95\% CI, 0.57-1.27) compared to 0.62 (95\% CI, 0.47-0.83) in PIK3CA mutation-negative patients [61]. However, patients with two or more mutations in PIK3CA had a superior progression free survival compared to those with only one mutation, i.e., HR of 0.37 versus 0.68. It should be stated however, that although this trial met its primary endpoint, taselisib plus fulvestrant was deemed to lack clinical utility due its toxicity and modest clinical benefit [61]. 


\section{Mutant RAS for Predicting Resistance to Anti-EGFR Antibodies in Patients with Colorectal Cancer}

Mutation testing of RAS (KRAS and NRAS) in tumour tissue has been routinely used for several years to identify patients with advanced $C R C$ who are intrinsically resistant to anti-EGFR antibodies (cetuximab, panitumumab) [62]. Thus, the most recent guidelines published jointly by the American Society for Clinical Pathology, College of American Pathologists, Association for Molecular Pathology, and the American Society of Clinical Oncology state that colorectal carcinoma patients being considered for anti-EGFR therapy must undergo RAS mutational testing. Mutational analysis should include $K R A S$ and NRAS codons 12, 13 of exon 2; 59, 61 of exon 3; and 117 and 146 of exon 4 [63].

As with EGFR mutations in advanced NSCLC and PIK3CA mutations in advanced breast cancer, strong concordance has been found between the $R A S$ mutational status of CRC tissue and matching plasma in patients with advanced CRC [62,64-66]. Thus, across seven independent studies, concordance between the two sites was found to vary from $78 \%$ to $96 \%$, while the sensitivities and specificities of ctDNA varied from $72 \%$ to $96 \%$ and $83 \%$ and $98 \%$, respectively [62]. Lower sensitivity was found in patients with nodal, peritoneal or lung metastases as well as in those with mucinous-type tumours [62].

Consistent with this high concordance, retrospective studies have reported that the outcome of patients with advanced CRC treated with cetuximab or panitumumab was similar, irrespective of whether RAS mutation testing was performed using tissue or plasma [64-66]. We should however, mention that although most reports showed similar predictive value for ctDNA and tissue assays, a small exploratory study concluded that a positive ctDNA $R A S$ mutations result did not preclude response to panitumumab, i.e., $11 \%$ of patients with a plasma-positive test had either a complete or partial response to the antibody [67]. Clearly, the findings in this provocative preliminary report require confirmation.

Despite the overall good concordance between tissue and plasma, most expert panels continue to recommend that $R A S$ mutation assays for predicting response to anti-EGFR antibodies in CRC are performed on tissue. However, according to the European Society of Digestive Oncology (ESDO) expert panel, a ctDNA assay could be used when obtaining tissue is technically or logistically not possible [68]. As well as ESDO, the Japanese Society of Medical Oncology recommend ctDNA testing for "evaluating the suitability" of antiEGFR therapy in patients with unresectable CRC [69]. One of the obstacles to having a clinically useful ctDNA assay for ctDNA $R A S$ mutations is lack of prospective validation and lack of a validated cut-off point for RAS mutations.

One of the first commercially available ctDNA for detecting mutations in $R A S$ to have received regulatory approval was OncoBEAM ${ }^{\mathrm{TM}}$ RAS CRC which has obtained the EU CE Mark IVD status (Sysmex). This test uses a form of digital PCR (BEAMing technology) to detect 34 mutations in KRAS and NRAS [70].

Although CRC patients with wild-type RAS may initially benefit from anti-EGFR antibody therapy, acquired resistance is inevitable and usually occurs within the first year of treatment. One of the most frequent mechanisms of acquired resistance involves secondary mutations in $R A S$ (KRAS and NRAS) which are found in approximately one third of cases [71]. However, alteration in other genes, including mutations in EGFR (extracellular domain), BRAF (V600E), MEK as well as amplification of HER2 and MET, has also been associated with the development of acquired resistance [72,73]. Although all of these alterations have been detected in ctDNA [72,73], they are not currently actionable.

Interestingly, cessation of anti-EGFR therapy, followed by a break from these drugs, leads to a decrease in ctDNA $R A S$ mutations, opening up the possibility for rechallenge with anti-EGFR therapy. To test this hypothesis, Cremolini et al. [74] initiated a single-arm phase II trial to evaluate the efficacy of cetuximab plus irinotecan for third-line treatment of patients with $R A S$ and $B R A F$ wild-type metastatic CRC who were initially sensitive to and then developed resistance to the therapy. After a median follow-up of 15.4 months, patients with $R A S$ wild-type ctDNA $(n=13)$ were found to have a significantly longer progressionfree survival than those with ctDNA positive for $R A S$ mutations $(n=12)$. The corresponding 
median progression-free survival periods were 4.0 and 1.9 months, respectively (HR, 0.44 ; 95\% CI, 0.18-0.98; $p=0.03$ ). At time of follow-up, no significant difference was found in overall survival between the groups. In a further phase II trial (CAVE trial), rechallenge with cetuximab and avelumab (an anti PD-L1 antibody) was also found to provide more benefit in ctDNA wild-type than ctDNA KRAS mutant patients (median overall survival, 17.3 months versus 10.4 months [75]. Clearly, these results now require confirmation in prospective randomised trials.

\section{Other ctDNA Predictive Biomarkers and Companion Diagnostics}

In recent years, the USA FDA approved several new companion diagnostics for identifying patients with different types of metastatic cancer likely to benefit from specific therapies. These included:

- The FoundationOne Liquid CDx test for mutant BRCA1 and BRCA2 in patients with ovarian cancer eligible for treatment with the PARP inhibitor, rucaparib; $A L K$ rearrangements in patients with NSCLC eligible for treatment with the ALK inhibitor, alectinib and mutant $B R C A 1, B R C A 2$ and $A T M$ in patients with metastatic castrationresistant prostate cancer eligible for treatment with the PARP inhibitor, olaparib.

- The Guardant360 CDx for the EGFR mutations ex19del, L858R and T790M for predicting response to osimertinib in patients with NSCLC and KRAS G12C for predicting response to the RAS inhibitor sotorasib, also in NSCLC.

- Therascreen KRAS RGQ PCT kit, also for predicting response to sotorasib in patients with NSCLC.

However, the FDA again added that if the specific genetic alterations associated with response to these therapeutics were not detected in blood, then a tumour biopsy should be performed to determine if the specific alterations were present.

In addition to these approved tests, several emerging therapy predictive and resistance biomarkers measurable using ctDNA have recently been reported. These include mutant $H E R 2$ for predicting response to neratinib in metastatic breast cancer [76,77], mutant AKT1 for predicting response to capivasertib, also in breast cancer [77], and tumour mutational burden for predicting response to immune checkpoint-based immunotherapy in advanced NSCLC [78-80]. Emerging resistance-conferring genetic alterations found using ctDNA include mutations in ESR1 (codes for ER) in patients with breast cancer who develop resistance to aromatase inhibitors [81,82], reversion mutations in $B R C A 1 / 2$ genes in patients with diverse solid cancers that develop resistance to PARP inhibitors [83] and mutations in FGFR2 in patients with cholangiocarcinoma who become resistant to FGFR inhibitor [84]. Currently, however, these resistance mechanisms are not directly actionable.

\section{From One Gene and One Drug to Multigenes and Multidrugs}

The traditional approach for analysing predictive biomarkers/companion diagnostics has involved the measurement of mutations in only one gene (usually by PCR) to select for response to a single therapeutic. However, with the decreasing costs of next generation sequencing (NGS), leading to its increased availability as well as the increasing numbers of multiple therapies for some cancer types (e.g., NSCLC and CRC), several clinical trials now require testing for mutations in multiple genes using NGS. Indeed, measurement of multiple predictive genes/companion diagnostics is currently recommended by a least one expert panel, i.e., the National Comprehensive Cancer Network (NCCN), for patients with NSCLC [45]. Until recently, most NGS analysis was performed on tissue rather than ctDNA.

One of the first reports describing the feasibility of using ctDNA as a substitute for tumour tissue was the TARGET study [85]. In part A of this study which included 100 patients with a variety of advanced cancers, Rothwell et al. [85], using a 641-gene panel, showed that successful analysis was achieved in $99 \%$ of the ctDNA samples compared with $95 \%$ for tissue. Overall, a concordance of $75 \%$ was obtained between the mutational status of the two sources. Actionable mutations were detected in ctDNA from 41 patients, of which 11 received a matching therapy as part of a phase I trial. Of these 11 patients, 
4 exhibited a partial response. Unlike other reports [26,27], the turn-around times for reporting of results in this study was similar for ctDNA and tumour tissue (mean of 33 days versus 30 days, respectively).

Subsequently, large prospective phase IIa multicentre trials tested the potential clinical utility of multigene analysis of ctDNA for therapy selection in patients with advanced breast cancer [77]. In this study (plasmaMATCH), which included 1034 patients, plasma mutations in ESR1, PIK3CA, HER2 AKT1 and PTEN were measured by ddPCR in all participating subjects and by the Guardant360 assay in 800 subjects. Sensitivity of the PCR ctDNA testing for mutations identified in matching tissue sequencing was $93 \%$ overall but reached $98 \%$ in samples where contemporaneous biopsies were analysed.

Patients were divided into four cohorts as follows: those with ESR1 mutations were treated with fulvestrant; those with HER2 mutations received neratinib, and if ER-positive also fulvestrant; those with $A K T 1$ mutations and ER-positive cancer received capivasertib plus fulvestrant; while those with $A K T 1$ mutations and were ER-negative cancer or had PTEN mutations were treated with capivasertib alone. After a median follow-up of 14.4 months, patients with HER2 mutations treated with neratinib and those with ERpositive disease and $A K T$ mutations treated with capivasertib plus fulvestrant reached the target number of responses, i.e., 5/20 (25\%) and 4/18 (22\%), respectively. According to the authors, these response rates were similar with those previously found with respective tissue assays. In contrast, findings from the other two cohorts failed to reach the pre-set target number of responses.

In another study using ctDNA multigene analysis, Nakamura et al. [86] compared the effectiveness of plasma versus tissue assays for enrolling patients with advanced gastrointestinal cancers, into clinical trials. Tissue assays were performed as part of the GI-SCREEN trial $(n=5743)$, while the ctDNA measurements were performed in patients participating in the GOZILA trial $(n=1787)$. Sequencing of ctDNA was carried using the Guardant360 assay, while tissue sequencing was performed using the OCA (v 1 and 3) method. According to the authors, the demographics and clinical characteristics of the patients were similar in the two studies, except for the prevalence of pancreatic ductal adenocarcinoma, which was higher in GOZILA trial than in GI-SCREEN (22\% versus 11\%).

To compare ctDNA and tissue mutation concordance, 232 patients with CRC had both assays performed. Depending on the specific gene, the overall concordance between the two sources varied between 85.0 and $100 \%$ but this increased to 97.0 to $100 \%$ for clonal mutations. Importantly, ctDNA testing was found to significantly shorten the screening duration (11 versus 33 days, $p<0.0001)$ and improve trial enrolment $(9.5$ versus $4.1 \%$, $p<0.0001$ ) without compromising treatment efficacy, compared to tissue testing.

The results of these trials suggest that ctDNA-based multigene mutation NGS assays have sufficient accuracy in selecting patients for participating in therapy-related clinical trials and perhaps later for widespread adoption into clinical practice.

\section{Limitations of ctDNA Testing for Predictive Biomarkers/Companion Diagnostics}

\subsection{Limited Sensitivity for Low Volume Tumours}

While the use of ctDNA versus tissue has several advantages for therapy prediction assays (Table 2), it also has several limitations (Table 3). One of the major limitations is that not all tumours, even in an advanced state, release ctDNA into the circulation. In particular, low volume tumours generally shed less ctDNA than larger samples [87]. In addition, some types of tumour such as those occurring in the brain tend to release lower levels of ctDNA into blood compared to colorectal, liver or lung lesions $[87,88]$. For patients with brain tumours shedding little or no detectable DNA into the bloodstream, testing for mutations in CSF might be possible [89]. Potential approaches to increase sensitivity include taking larger volumes of blood (not always possible), using ultra-low sensitive sequencing, combining mutational and methylation measurements, measurement of the corresponding mRNA (see below) or using fluids other than blood (e.g., urine for bladder cancers, CSF for brain cancers, saliva for oral cancers). 
Table 3. Disadvantages of ctDNA assays for detecting predictive biomarkers/companion compared with tissue assays.

\begin{tabular}{c}
\hline Less Sensitive, May Miss Tissue-Positive Samples \\
\hline Susceptible to misinterpretation due to CHIP * \\
\hline Unable to determine if detected mutant gene is expressed \\
\hline Unable to detect certain potentially actionable gene fusions \\
\hline Unable to identify non-genetic mechanisms of resistance \\
\hline Only a small number have validated or approved assays \\
Requires deeper DNA sequencing
\end{tabular}

* CHIP, clonal haematopoiesis of indeterminate origin, can be eliminated or minimised by simultaneously sequencing matching white cell DNA or performing mutation analysis on plasma low molecular weight DNA fragments.

\subsection{Interference by CHIP}

Overall, the specificity of ctDNA versus tissue for actionable driver mutations is excellent, see above. However, some mutations/variants detected in plasma may not be derived from tumours but from a benign disorder known as clonal haematopoiesis of indeterminate potential (CHIP) [90]. CHIP involves clonal expansion of myeloid stem cells in the bone marrow and occurs in $>10 \%$ of apparently healthy individuals $>70$ years. Myeloid cells acquire mutations, especially in leukaemia-associated genes such as DNMT3A, TET2, TP53 JAK2 and ASXL1. DNA containing these mutations can be shed and detected in plasma where their presence may confound the interpretation of predictive ctDNA assays [90].

The prevalence of CHIP-associated mutations/variants in patients with cancer reported in the literature has been found to vary from $<1 \%$ to $62 \%[91,92]$. This wide variation is likely to be due to method used in sequencing DNA (e.g., breadth and depth of sequencing) and/or characteristics of patients studied (e.g., previous treatments, age of patients). Fortunately, most of the CHIP-derived mutant/variant genes are not currently actionable for solid tumour, although a JAK2 inhibitor (fedratinib) has been approved by the US FDA for the treatment of the rare bone marrow disease, myelofibrosis. Strong actionable genes with predictive potential such as mutant EGFR, amplified or mutant HER2 or mutant PIK3CA do not appear to be commonly associated with CHIP. However, mutant KRAS, apparently derived from CHIP, was found in ctDNA from 3/236 patients with metastatic CRC [93]. All of these patients however, received prior chemotherapy. As mentioned above, mutant KRAS in tissue is widely used to predict intrinsic resistance to anti-EGFR antibodies in patients with metastatic CRC. However, at present the ctDNA assay for RAS mutations is not widely used.

Evidence that CHIP may lead to misinterpretation of predictive ctDNA assays was recently reported in a study involving men with advanced prostate cancer who were undergoing plasma mutation testing for potential response to PARP inhibitors [94]. Approximately $10 \%$ of these men were found to have CHIP-related mutations in the DNA repair genes CHEK2, BRCA2 and ATM that potentially could have led to false-positive findings. Interference of CHIP-derived genes in ctDNA assays however, can be filtered out or minimised by sequencing DNA from paired white cells. A further advantage of sequencing white cell DNA is that it can also result in germline alterations being filtered out [95].

In addition to CHIP, other lesions such as cancer precursor lesions, benign clonal expansions or incidental occult tumours unrelated to the cancer of interest could also shed mutant DNA into the circulation. There is however, little evidence that benign lesions other that CHIP release mutant DNA into the circulation. 


\subsection{Difficulties in Analysing If Mutant Actionable Gene Is Expressed}

It is sometimes forgotten that not all genes including mutated genes are consistently expressed. Thus, in a study in which 1417 different tumour types were subjected to whole exome and whole-transcriptome sequencing, $13 \%$ of the identified somatic mutation/variants genes were not found to be expressed or expressed in low levels at the mRNA level [96]. Amongst the potentially actionable genes not expressed or expressed at low levels, were $A L K$ and RET. The ALK gene is translocated in 3-5\% of patients with NSCLC and is a validated target for at least five approved therapeutics for this malignancy, i.e., crizotinib, ceritinib, alectinib, brigatinib, and lorlatinib [97]. RET gene alterations are also found in a small proportion of patients with NSCLC, but additionally, can be present in certain histological types of thyroid cancer (medullary and papillary). Selpercatinib and pralsetinib are approved therapeutics for targeting RET alteration in these malignancies [98].

Thus, to enhance the number of targetable mutations, the expression of potentially actionable genes should also be measured. Support for combined analysis was recently obtained by Sailer et al. [99] who reported that the number of patients matched for a targeted therapy increased from $39 \%$ to $55 \%$ when whole exome RNA-seq was performed in addition to DNA-seq. Although combined measurement of DNA and RNA analysis may increase, the number of actionable genes detected, we still lack suitable assays for detecting what should approximate the ideal predictive biomarker, i.e., level and/or activity of the protein drug target.

Evidence that analysing all three types of molecules can increase the number of patients matched for targeted therapies was recently obtained by Beaubier et al. [100]. These authors reported that combining measurement of DNA, mRNA alterations and immunological protein biomarkers increased the number of actionable mutations form $29.6 \%$ with DNA alone to $43.4 \%$ [100]. While DNA, mRNA and specific proteins (e.g., oestrogen receptors, HER2, PD-L1) analysis can be performed on tissue, neither mRNA or oncoproteins can be readily measured in plasma (mRNA, due to its instability and low concentration; protein because of the uncertainty of its tissue of origin when measure in blood). This limitation, however, might be minimised by using circulating tumour cells (CTC) or extracellular vesicles $(\mathrm{EV})$.

\section{4. ctDNA Not Suitable for Detecting Certain Gene Alterations}

Some actionable genetic alterations such as fusions involving large intronic sequences are best detected at mRNA level rather than using DNA [101]. For example, in 2522 cases of NSCLC that were negative for actionable genes using an FDA-cleared DNA assay (MSK-IMPACT), 232 samples had RNA-seq performed [102]. Of these, 36 cases, (15.5\% of tested cases) were positive for an actionable target that was not detected at the DNA level. Importantly, $8 / 10(80 \%)$ patients derived clinical benefit when their treatment was based on the molecular alteration identified at the RNA level. As mentioned above, while both DNA and RNA-seq can be performed on tissues in most cases, RNA analysis cannot be easily carried out using plasma. Again this problem might be overcome by analysing CTC or EV. Finally, ctDNA may not be suitable for detecting copy-number variant such as deletions or shallow gains, especially when its abundance is low [103].

\section{5. ctDNA Unable to Identify Non-Genetic Mechanisms of Resistance}

While most of the published literature has focused on genetic mechanisms of drug resistance, resistance can also be mediated by non-genetic alterations such as cell-type switching and stromal remodelling. Such mechanisms of resistance have been identified in CRC patients treated with the anti-EGFR antibody, cetuximab [104] and in NSCLC patients treated with EGFR TKIs [105].

\section{Clinical Implementation of ctDNA Mutation Testing}

Currently, most guidelines published by expert panels recommend ctDNA mutation testing only when tissue is unavailable or unsuitable for analysis. A possible alternative 
strategy is to initially perform ctDNA analysis and only reflex to tissue if the ctDNA result is negative. This is a reasonable approach given the high specificity and high positive predictive value of the plasma test. Also, according to van't Erve et al. [106], this approach has the potential to be cost-saving compared to up-front tissue testing. Furthermore, for those patients who have a ctDNA positive result, therapy might be started earlier than waiting for a tissue result. On the contrary, waiting for a tissue result following a negative ctDNA test could delay the start of treatment. Yet a further potential strategy might be to perform combined tissue and ctDNA testing on all patients. This approach could increase the number of actionable mutations identified and thus the proportion of patients benefiting from a specific therapy [23-26,92]. However, it would be more expensive and prolong the turn-around-time for results. In addition, it is still unclear if patients who are tissue-negative but ctDNA-positive benefit from matching therapy.

\section{Conclusions}

Although tissue testing remains the gold standard for analysis of predictive biomarkers and companion diagnostics, the use of ctDNA has several attractions including ease of use and convenience, more rapid turn-around-time for reporting of results and an ability to perform serial testing. Additionally, use of ctDNA will potentially allow more patients to receive targeted therapy [23-26]. The main limitation of ctDNA testing is lower sensitivity than that available from tissue. Going forward, it will be thus important to improve sensitivity without negatively impacting on specificity. In addition, it will be important to validate (analytically and clinically) other ctDNA-based predictive biomarkers/companion diagnostics, especially $R A S$ mutation testing for predicting resistance to anti-EGFR antibodies in patients with CRC. Future research should aim to increase the number of patients benefiting from matched therapies by performing mutational analysis on specific proximal fluids in addition to plasma and investigating the potential benefit of evaluating other types of liquid biopsy assays (CTC, EV) which might enable RNA analysis to be performed in addition to DNA.

Author Contributions: M.J.D. reviewed the literature and wrote the initial drafts of the article. J.C. reviewed and edited the article. All authors have read and agreed to the published version of the manuscript.

Funding: The research was funded by Cancer Clinical Research Trust.

Institutional Review Board Statement: Not applicable.

Informed Consent Statement: Not applicable.

Data Availability Statement: Not applicable.

Acknowledgments: We thank the Cancer Clinical Research Trust for funding this work.

Conflicts of Interest: M.J.D. has no conflicts of interest. J.C. has received honoraria from Eisai, Amgen, Puma Biothechnology, Seattle Genetics, Boehringer Ingelheim, Pfizer, Vertex and Genomic Health. He has acted in an advisory/consulting role to Eisai, Puma Biotechnology, Boehringer Ingelheim, Pfizer, Vertex, Roche. He also serves on the Speakers' Bureau for Pfizer, Eisai and Genomic Health and has received Research Funding from Roche, Eisai, Boehringer Ingelheim and Puma Biotechnology. In addition, he has received travel, accommodation and expenses from MSD, Pfizer, Roche, AstraZeneca, Abbvie and Novartis. Finally, he is an employee of OncoMark, has stocks in OncoMark and is named on patent WO2020011770 (A1)_A method of predicting response to treatment in cancer patients.

\section{References}

1. Keller, L.; Belloum, Y.; Wikman, H.; Pantel, K. Clinical relevance of blood-based ctDNA analysis: Mutation detection and beyond. Br. J. Cancer 2021, 124, 345-358. [CrossRef]

2. Ignatiadis, M.; Sledge, G.W.; Jeffrey, S.S. Liquid biopsy enters the clinic-implementation issues and future challenges. Nat. Rev. Clin. Oncol. 2021, 18, 297-312. [CrossRef] [PubMed]

3. Kilgour, E.; Rothwell, D.G.; Brady, G.; Dive, C. Liquid biopsy-based biomarkers of treatment response and resistance. Cancer Cell 2020, 37, 485-495. [CrossRef] [PubMed] 
4. Slamon, D.J.; Leyland-Jones, B.; Shak, S.; Fuchs, H.; Paton, V.; Bajamonde, A.; Fleming, T.; Eiermann, W.; Wolter, J.; Pegram, M.; et al. Use of chemotherapy plus a monoclonal antibody against HER2 for metastatic breast cancer that overexpresses HER2. N. Engl. J. Med. 2001, 344, 783-792. [CrossRef] [PubMed]

5. $\quad$ Douillard, J.Y.; Oliner, K.S.; Siena, S.; Tabernero, J.; Burkes, R.; Barugel, M.; Humblet, Y.; Bodoky, G.; Cunningham, D.; Jassem, J.; et al. Panitumumab-FOLFOX4 treatment and RAS mutations in colorectal cancer. N. Engl. J. Med. 2013, 369, 1023-1034. [CrossRef]

6. Mok, T.S.; Wu, Y.L.; Thongprasert, S.; Yang, C.H.; Chu, D.T.; Saijo, N.; Sunpaweravong, P.; Han, B.; Margono, B.; Ichinose, Y.; et al. Gefitinib or carboplatin-paclitaxel in pulmonary adenocarcinoma. N. Engl. J. Med. 2009, 361, 947-957. [CrossRef]

7. Rosell, R.; Carcereny, E.; Gervais, R.; Vergnenegre, A.; Massuti, B.; Felip, E.; Palmero, R.; Garcia-Gomez, R.; Pallares, C.; Sanchez, J.M.; et al. Erlotinib versus standard chemotherapy as first-line treatment for European patients with advanced EGFR mutationpositive non-small-cell lung cancer (EURTAC): A multicentre, open-label, randomised phase 3 trial. Lancet Oncol. 2012, 13, 239-246. [CrossRef]

8. Koch, A.L.; Vellanki, P.J.; Drezner, N.; Li, X.; Mishra-Kalyani, P.S.; Shen, Y.L.; Xia, H.; Li, Y.; Liu, J.; Zirkelbach, J.F.; et al. FDA Approval Summary: Osimertinib for Adjuvant Treatment of Surgically Resected Non-Small Cell Lung Cancer, a Collaborative Project Orbis Review. Clin. Cancer Res. 2021, 27, 6638-6643. [CrossRef]

9. Chapman, P.B.; Hauschild, A.; Robert, C.; Haanen, J.B.; Ascierto, P.; Larkin, J.; Dummer, R.; Garbe, C.; Testori, A.; Maio, M.; et al Improved survival with vemurafenib in melanoma with BRAF V600E mutation. N. Engl. J. Med. 2011, 364, 2507-2516. [CrossRef]

10. Shitara, K.; Bang, Y.J.; Iwasa, S.; Sugimoto, N.; Ryu, M.H.; Sakai, D.; Chung, H.C.; Kawakami, H.; Yabusaki, H.; Lee, J.; et al. Trastuzumab Deruxtecan in previously treated HER2-positive gastric cancer. N. Engl. J. Med. 2020, 382, 2419-2430. [CrossRef]

11. Garon, E.B.; Hellmann, M.D.; Rizvi, N.A.; Carcereny, E.; Leighl, N.B.; Ahn, M.J.; Eder, J.P.; Balmanoukian, A.S.; Aggarwal, C.; Horn, L.; et al. Five-year overall survival for patients with advanced non-small-cell lung cancer treated with pembrolizumab: Results from the phase I KEYNOTE-001 Study. J. Clin. Oncol. 2019, 37, 2518-2527. [CrossRef]

12. André, T.; Shiu, K.K.; Kim, T.W.; Jensen, B.V.; Jensen, L.H.; Punt, C.; Smith, D.; Garcia-Carbonero, R.; Benavides, M.; Gibbs, P.; et al. Pembrolizumab in microsatellite-instability-high advanced colorectal cancer. N. Engl. J Med. 2020, 383, 2207-2218. [CrossRef]

13. Kurnit, K.C.; Dumbrava, E.E.I.; Litzenburger, B.; Khotskaya, Y.B.; Johnson, A.M.; Yap, T.A.; Rodon, J.; Zeng, J.; Shufean, M.A.; Bailey, A.M.; et al. Precision oncology decision support: Current approaches and strategies for the future. Clin. Cancer Res. 2018, 24, 2719-2731. [CrossRef] [PubMed]

14. El-Deiry, W.S.; Goldberg, R.M.; Lenz, H.J.; Shields, A.F.; Gibney, G.T.; Tan, A.R.; Brown, J.; Eisenberg, B.; Heath, E.I.; Phuphanich, S.; et al. The current state of molecular testing in the treatment of patients with solid tumors, 2019. CA Cancer J. Clin. 2019, 69, 305-343. [CrossRef]

15. Mosele, F.; Remon, J.; Mateo, J.; Westphalen, C.B.; Barlesi, F.; Lolkema, M.P.; Normanno, N.; Scarpa, A.; Robson, M.; MericBernstam, F.; et al. Recommendations for the use of next-generation sequencing (NGS) for patients with metastatic cancers: A report from the ESMO Precision Medicine Working Group. Ann. Oncol. 2020, 31, 1491-1505. [CrossRef]

16. Ignatiadis, M.; Lee, M.; Jeffrey, S.S. Circulating tumor cells and circulating tumor DNA: Challenges and opportunities on the path to clinical utility. Clin. Cancer Res. 2015, 21, 4786-4800. [CrossRef]

17. Sholl, L.M.; Aisner, D.L.; Varella-Garcia, M.; Berry, L.D.; Dias-Santagata, D.; Wistuba, I.I.; Chen, H.; Fujimoto, J.; Kugler, K.; Franklin, W.A.; et al. Multi-institutional oncogenic driver mutation analysis in lung adenocarcinoma: The Lung Cancer Mutation Consortium Experience. J. Thorac. Oncol. 2015, 10, 768-777. [CrossRef] [PubMed]

18. Hasegawa, T.; Sawa, T.; Futamura, Y.; Horiba, A.; Ishiguro, T.; Marui, T.; Yoshida, T. Feasibility of rebiopsy in non-small cell lung cancer treated with epidermal growth factor receptor-tyrosine kinase inhibitors. Intern. Med. 2015, 54, 1977-1980. [CrossRef] [PubMed]

19. Angus, L.; Smid, M.; Wilting, S.M.; van Riet, J.; van Hoeck, A.; Nguyen, L.; Nik-Zainal, S.; Steenbruggen, T.G.; Tjan-Heijnen, V.C.; Labots, M.; et al. The genomic landscape of metastatic breast cancer highlights changes in mutation and signature frequencies. Nat. Genet. 2019, 51, 1450-1458. [CrossRef]

20. Aggarwal, C.; Thompson, J.C.; Black, T.A.; Katz, S.I.; Fan, R.; Yee, S.S.; Chien, A.L.; Evans, T.L.; Bauml, J.M.; Alley, E.W.; et al. Clinical implications of plasma-based genotyping with the delivery of personalized therapy in metastatic non-small cell lung cancer. JAMA Oncol. 2019, 5, 173-180. [CrossRef]

21. McGranahan, N.; Swanton, C. Clonal heterogeneity and tumor evolution: Past, present, and the future. Cell 2017, 168, 613-628. [CrossRef]

22. Parikh, A.R.; Leshchiner, I.; Elagina, L.; Goyal, L.; Levovitz, C.; Siravegna, G.; Livitz, D.; Rhrissorrakrai, K.; Martin, E.E.; van Seventer, E.E.; et al. Liquid versus tissue biopsy for detecting acquired resistance and tumor heterogeneity in gastrointestinal cancers. Nat Med. 2019, 25, 1415-1421. [CrossRef] [PubMed]

23. Leighl, N.B.; Page, R.D.; Raymond, V.M.; Daniel, D.B.; Divers, S.G.; Reckamp, K.L.; Villalona-Calero, M.A.; Dix, D.; Odegaard, J.I.; Lanman, R.B.; et al. Clinical utility of comprehensive cell-free DNA analysis to identify genomic biomarkers in patients with newly diagnosed metastatic non-small cell lung cancer. Clin. Cancer Res. 2019, 25, 4691-4700. [CrossRef] [PubMed]

24. Vidula, N.; Niemierko, A.; Malvarosa, G.; Yuen, M.; Lennerz, J.; Iafrate, A.J.; Wander, S.A.; Spring, L.; Juric, D.; Isakoff, S.; et al. Tumor tissue- versus plasma-based genotyping for selection of matched therapy and impact on clinical outcomes in patients with metastatic breast cancer. Clin. Cancer Res. 2021, 27, 3404-3413. [CrossRef] 
25. Tukachinsky, H.; Madison, R.W.; Chung, J.H.; Gjoerup, O.V.; Severson, E.A.; Dennis, L.; Fendler, B.J.; Morley, S.; Zhong, L.; Graf, R.P.; et al. Genomic analysis of circulating tumor DNA in 3334 patients with advanced prostate cancer identifies targetable BRCA alterations and AR resistance mechanisms. Clin. Cancer Res. 2021, 27, 3094-3105. [CrossRef]

26. Thierry, A.R.; El Messaoudi, S.; Mollevi, C.; Raoul, J.L.; Guimbaud, R.; Pezet, D.; Artru, P.; Assenat, E.; Borg, C.; Mathonnet, M.; et al. Clinical utility of circulating DNA analysis for rapid detection of actionable mutations to select metastatic colorectal patients for anti-EGFR treatment. Ann. Oncol. 2017, 28, 2149-2159. [CrossRef] [PubMed]

27. Sabari, J.K.; Offin, M.; Stephens, D.; Ni, A.; Lee, A.; Pavlakis, N.; Clarke, S.; Diakos, C.I.; Datta, S.; Tandon, N.; et al. A Prospective Study of Circulating Tumor DNA to Guide Matched Targeted Therapy in Lung Cancers. J. Natl. Cancer Inst. 2019, 111, 575-583. [CrossRef] [PubMed]

28. Oellerich, M.; Christenson, R.H.; Beck, J.; Walson, P.D. Plasma EGFR mutation testing in non-small cell lung cancer: A value proposition. Clin. Chim. Acta 2019, 495, 481-486. [CrossRef] [PubMed]

29. Ontario Health (Quality). Cell-Free Circulating Tumour DNA Blood Testing to Detect EGFR T790M Mutation in People with Advanced Non-Small Cell Lung Cancer: A Health Technology Assessment. Ont. Health Technol. Assess. Ser. 2020, $20,1-176$.

30. Diao, Z.; Han, Y.; Zhang, R.; Li, J. Circulating tumour DNA: A new biomarker to monitor resistance in NSCLC patients treated with EGFR-TKIs. Biochim. Biophys. Acta Rev. Cancer 2020, 1873, 188363. [CrossRef]

31. Yang, C.Y.; Yang, J.C.; Yang, P.C. Precision management of advanced non-small cell lung cancer. Annu. Rev. Med. 2020, 71, 117-136. [CrossRef] [PubMed]

32. Thai, A.A.; Solomon, B.J.; Sequist, L.V.; Gainor, J.F.; Heist, R.S. Lung cancer. Lancet 2021, 398, 535-554. [CrossRef]

33. Howlader, N.; Forjaz, G.; Mooradian, M.J.; Meza, R.; Kong, C.Y.; Cronin, K.A.; Mariotto, A.B.; Lowy, D.R.; Feuer, E.J. The effect of advances in lung-cancer treatment on population mortality. N. Engl. J. Med. 2020, 383, 640-649. [CrossRef]

34. Ramalingam, S.S.; Vansteenkiste, J.; Planchard, D.; Cho, B.C.; Gray, J.E.; Ohe, Y.; Zhou, C.; Reungwetwattana, T.; Cheng, Y.; Chewaskulyong, B.; et al. Overall survival with osimertinib in untreated, EGFR-mutated advanced NSCLC. N. Engl. J. Med. 2020, 382, 41-50. [CrossRef]

35. Hanna, N.H.; Robinson, A.G.; Temin, S.; Baker, S., Jr.; Brahmer, J.R.; Ellis, P.M.; Gaspar, L.E.; Haddad, R.Y.; Hesketh, P.J.; Jain, D.; et al. Therapy for Stage IV Non-Small-Cell Lung Cancer with Driver Alterations: ASCO and OH (CCO) Joint Guideline Update. J. Clin. Oncol. 2021, 39, 1040-1091. [CrossRef]

36. Qian, X.; Liu, J.; Sun, Y.; Wang, M. Circulating cell-free DNA has a high degree of specificity to detect exon 19 deletions and the single-point substitution mutation L858R in non-small cell lung cancer. Oncotarget 2016, 7, 29154-29165. [CrossRef]

37. Sacher, A.G.; Paweletz, C.; Dahlberg, S.E.; Alden, R.S.; O'Connell, A.; Feeney, N.; Mach, S.L.; Jänne, P.A.; Oxnard, G.R. Prospective validation of rapid plasma genotyping for the detection of EGFR and KRAS mutations in advanced lung cancer. JAMA Oncol. 2016, 2, 1014-1022. [CrossRef]

38. Sacher, A.G.; Komatsubara, K.M.; Oxnard, G.R. Application of plasma genotyping technologies in non-small cell lung cancer: A practical review. J. Thorac. Oncol. 2017, 12, 1344-1356. [CrossRef] [PubMed]

39. Shah, P.; Sands, J.; Normanno, N. The expanding capability and clinical relevance of molecular diagnostic technology to identify and evaluate EGFR mutations in advanced/metastatic NSCLC. Lung Cancer 2021, 160, 118-126. [CrossRef]

40. Gray, J.E.; Okamoto, I.; Sriuranpong, V.; Vansteenkiste, J.; Imamura, F.; Lee, J.S.; Pang, Y.K.; Cobo, M.; Kasahara, K.; Cheng, Y.; et al. Tissue and plasma EGFR mutation analysis in the Flaura trial: Osimertinib versus comparator EGFR tyrosine kinase inhibitor as first-line treatment in patients with EGFR-mutated advanced non-small cell lung cancer. Clin. Cancer Res. 2019, 25, 6644-6652. [CrossRef]

41. Palmero, R.; Taus, A.; Viteri, S.; Majem, M.; Carcereny, E.; Garde-Noguera, J.; Felip, E.; Nadal, E.; Malfettone, A.; Sampayo, M.; et al. Biomarker Discovery and Outcomes for Comprehensive Cell-Free Circulating Tumor DNA Versus Standard-of-Care Tissue Testing in Advanced Non-Small-Cell Lung Cancer. JCO Precis. Oncol. 2021, 5, 93-102. [CrossRef] [PubMed]

42. Li, B.T.; Janku, F.; Jung, B.; Hou, C.; Madwani, K.; Alden, R.; Razavi, P.; Reis-Filho, J.S.; Shen, R.; Isbell, J.M.; et al. Ultra-deep next-generation sequencing of plasma cell-free DNA in patients with advanced lung cancers: Results from the Actionable Genome Consortium. Ann. Oncol. 2019, 30, 597-603. [CrossRef] [PubMed]

43. Kalemkerian, G.P.; Narula, N.; Kennedy, E.B. Molecular testing guideline for the selection of patients with lung cancer for treatment with targeted tyrosine kinase inhibitors: American Society of Clinical Oncology, Endorsement of the College of American Pathologists/International, Association for the Study of Lung Cancer/Association for Molecular Pathology Clinical Practice Guideline Update. J. Clin. Oncol. 2018, 36, 911-919. [PubMed]

44. Lindeman, N.I.; Cagle, P.T.; Aisner, D.L.; Arcila, M.E.; Beasley, M.B.; Bernicker, E.H.; Colasacco, C.; Dacic, S.; Hirsch, F.R.; Kerr, K.; et al. Updated molecular testing guideline for the selection of lung cancer patients for treatment with targeted tyrosine kinase inhibitors: Guideline from the College of American Pathologists, the International Association for the Study of Lung Cancer, and the Association for Molecular Pathology. J. Mol. Diagn. 2018, 20, 129-159. [PubMed]

45. Ettinger, D.S.; Wood, D.E.; Aisner, D.L.; Akerley, W.; Bauman, J.R.; Bharat, A.; Bruno, D.S.; Chang, J.Y.; Chirieac, L.R.; D'Amico, T.A.; et al. NCCN Guidelines insights: Non-small cell lung cancer, Version 2.2021. J. Natl. Compr. Cancer Netw. 2021, 19, 254-266. [CrossRef] [PubMed]

46. Rolfo, C.; Mack, P.; Scagliotti, G.V.; Aggarwal, C.; Arcila, M.E.; Barlesi, F.; Bivona, T.; Diehn, M.; Dive, C.; Dziadziuszko, R.; et al. Liquid biopsy for advanced NSCLC: A Consensus Statement From the International Association for the Study of Lung Cancer. J. Thorac. Oncol. 2021, 16, 1647-1662. [CrossRef] [PubMed] 
47. Oxnard, G.R.; Thress, K.S.; Alden, R.S.; Lawrance, R.; Paweletz, C.P.; Cantarini, M.; Yang, J.C.; Barrett, J.C.; Jänne, P.A. Association between plasma genotyping and outcomes of treatment with osimertinib (AZD9291) in advanced non-small-cell lung cancer. J. Clin. Oncol. 2016, 34, 3375-3382. [CrossRef] [PubMed]

48. Remon, J.; Caramella, C.; Jovelet, C.; Lacroix, L.; Lawson, A.; Smalley, S.; Howarth, K.; Gale, D.; Green, E.; Plagnol, V.; et al. Osimertinib benefit in EGFR-mutant NSCLC patients with T790M-mutation detected by circulating tumour DNA. Ann. Oncol. 2017, 28, 784-790. [CrossRef]

49. Papadimitrakopoulou, V.A.; Han, J.Y.; Ahn, M.J.; Ramalingam, S.S.; Delmonte, A.; Hsia, T.C.; Laskin, J.; Kim, S.W.; He, Y.; Tsai, C.M.; et al. Epidermal growth factor receptor mutation analysis in tissue and plasma from the AURA3 trial: Osimertinib versus platinum-pemetrexed for T790M mutation-positive advanced non-small cell lung cancer. Cancer 2020, 126, 373-380. [CrossRef]

50. Passiglia, F.; Rizzo, S.; di Maio, M.; Galvano, A.; Badalamenti, G.; Listì, A.; Gulotta, L.; Castiglia, M.; Fulfaro, F.; Bazan, V.; et al. The diagnostic accuracy of circulating tumor DNA for the detection of EGFR-T790M mutation in NSCLC: A systematic review and meta-analysis. Sci Rep. 2018, 8, 13379. [CrossRef]

51. Yasuda, H.; Kobayashi, S.; Costa, D.B. EGFR exon 20 insertion mutations in non-small-cell lung cancer: Preclinical data and clinical implications. Lancet Oncol. 2012, 13, e23-e31. [CrossRef]

52. Park, K.; Haura, E.B.; Leighl, N.B.; Mitchell, P.; Shu, C.A.; Girard, N.; Viteri, S.; Han, J.Y.; Kim, S.W.; Lee, C.K.; et al. Amivantamab in EGFR exon 20 insertion-mutated non-small-cell lung cancer progressing on platinum chemotherapy: Initial results from the CHRYSALIS phase I study. J. Clin. Oncol. 2021, 2, JCO2100662. [CrossRef]

53. Zhou, C.; Ramalingam, S.S.; Kim, T.M.; Kim, S.W.; Yang, J.C.; Riely, G.J.; Mekhail, T.; Nguyen, D.; Garcia Campelo, M.R.; Felip, E.; et al. Treatment Outcomes and Safety of mobocertinib in platinum-pretreated patients with EGFR exon 20 insertion-positive metastatic non-small cell lung cancer: A Phase 1/2 Open-label Nonrandomized Clinical Trial. JAMA Oncol. 2021, 7, e214761. [CrossRef] [PubMed]

54. Narayan, P.; Prowell, T.M.; Gao, J.J.; Fernandes, L.L.; Li, E.; Jiang, X.; Qiu, J.; Fan, J.; Song, P.; Yu, J.; et al. FDA Approval Summary: Alpelisib plus fulvestrant for patients with HR-positive, HER2-negative, PIK3CA-mutated, advanced or metastatic breast cancer. Clin. Cancer Res. 2021, 27, 1842-1849. [CrossRef]

55. Martínez-Sáez, O.; Chic, N.; Pascual, T.; Adamo, B.; Vidal, M.; González-Farré, B.; Sanfeliu, E.; Schettini, F.; Conte, B.; BrasóMaristany, F.; et al. Frequency and spectrum of PIK3CA somatic mutations in breast cancer. Breast Cancer Res. 2020, $22,45$. [CrossRef] [PubMed]

56. Li, A.; Schleicher, S.M.; Andre, F.; Mitri, Z.I. Genomic alteration in metastatic breast cancer and its treatment. Am. Soc. Clin. Oncol. Educ. Book 2020, 40, 30-43. [CrossRef]

57. Vasan, N.; Razavi, P.; Johnson, J.L.; Shao, H.; Shah, H.; Antoine, A.; Ladewig, E.; Gorelick, A.; Lin, T.Y.; Toska, E.; et al. Double PIK3CA mutations in cis increase oncogenicity and sensitivity to PI3K $\alpha$ inhibitors. Science 2019, 366, 714-723. [CrossRef] [PubMed]

58. Zhou, Y.; Wang, C.; Zhu, H.; Lin, Y.; Pan, B.; Zhang, X.; Huang, X.; Xu, Q.; Xu, Y.; Sun, Q. Diagnostic accuracy of PIK3CA mutation detection by circulating free DNA in breast cancer: A meta-analysis of diagnostic test accuracy. PLoS ONE 2016, 11, e0158143. [CrossRef] [PubMed]

59. André, F.; Ciruelos, E.; Rubovszky, G.; Campone, M.; Loibl, S.; Rugo, H.S.; Iwata, H.; Conte, P.; Mayer, I.A.; Kaufman, B.; et al. Alpelisib for PIK3CA-mutated, hormone receptor-positive advanced breast cancer. N. Engl. J. Med. 2019, 380, 1929-1940. [CrossRef]

60. André, F.; Ciruelos, E.M.; Juric, D.; Loibl, S.; Campone, M.; Mayer, I.A.; Rubovszky, G.; Yamashita, T.; Kaufman, B.; Lu, Y.S.; et al Alpelisib plus fulvestrant for PIK3CA-mutated, hormone receptor-positive, human epidermal growth factor receptor-2-negative advanced breast cancer: Final overall survival results from SOLAR-1. Ann Oncol. 2021, 32, 208-217. [CrossRef] [PubMed]

61. Dent, S.; Cortés, J.; Im, Y.H.; Diéras, V.; Harbeck, N.; Krop, I.E.; Wilson, T.R.; Cui, N.; Schimmoller, F.; Hsu, J.Y.; et al. Phase III randomized study of taselisib or placebo with fulvestrant in estrogen receptor-positive, PIK3CA-mutant, HER2-negative, advanced breast cancer: The SANDPIPER trial. Ann Oncol. 2021, 32, 197-207. [CrossRef]

62. Salem, M.E.; Puccini, A.; Tie, J. Redefining colorectal cancer by tumor biology. Am. Soc. Clin. Oncol. Educ. Book 2020, 40, 147-159. [CrossRef]

63. Sepulveda, A.R.; Hamilton, S.R.; Allegra, C.J.; Grody, W.; Cushman-Vokoun, A.M.; Funkhouser, W.K.; Kopetz, S.E.; Lieu, C.; Lindor, N.M.; Minsky, B.D.; et al. Molecular biomarkers for the evaluation of colorectal cancer: Guideline from the American Society for Clinical Pathology, College of American Pathologists, Association for Molecular Pathology, and the American Society of Clinical Oncology. J. Clin. Oncol. 2017, 35, 1453-1486. [CrossRef]

64. Grasselli, J.; Elez, E.; Caratù, G.; Matito, J.; Santos, C.; Macarulla, T.; Vidal, J.; Garcia, M.; Viéitez, J.M.; Paéz, D.; et al. Concordance of blood- and tumor-based detection of RAS mutations to guide anti-EGFR therapy in metastatic colorectal cancer. Ann. Oncol. 2017, 28, 1294-1301. [CrossRef] [PubMed]

65. Normanno, N.; Esposito Abate, R.; Lambiase, M.; Forgione, L.; Cardone, C.; Iannaccone, A.; Sacco, A.; Rachiglio, A.M.; Martinelli, E.; Rizzi, D.; et al. CAPRI-GOIM Investigators. RAS testing of liquid biopsy correlates with the outcome of metastatic colorectal cancer patients treated with first-line FOLFIRI plus cetuximab in the CAPRI-GOIM trial. Ann. Oncol. 2018, 29, 112-118. [CrossRef] [PubMed] 
66. Vidal, J.; Muinelo, L.; Dalmases, A.; Jones, F.; Edelstein, D.; Iglesias, M.; Orrillo, M.; Abalo, A.; Rodríguez, C.; Brozos, E.; et al. Plasma ctDNA RAS mutation analysis for the diagnosis and treatment monitoring of metastatic colorectal cancer patients. Ann. Oncol. 2017, 28, 1325-1332. [CrossRef]

67. Peeters, M.; Price, T.; Boedigheimer, M.; Kim, T.W.; Ruff, P.; Gibbs, P.; Thomas, A.; Demonty, G.; Hool, K.; Ang, A. Evaluation of emergent mutations in circulating cell-free DNA and clinical outcomes in patients with metastatic colorectal cancer treated with panitumumab in the ASPECT study. Clin. Cancer Res. 2019, 25, 1216-1225. [CrossRef] [PubMed]

68. Baraniskin, A.; van Laethem, J.L.; Wyrwicz, L.; Guller, U.; Wasan, H.S.; Matysiak-Budnik, T.; Gruenberger, T.; Ducreux, M.; Carneiro, F.; van Cutsem, E.; et al. Clinical relevance of molecular diagnostics in gastrointestinal (GI) cancer: European Society of Digestive Oncology (ESDO) expert discussion and recommendations from the 17th European Society for Medical Oncology (ESMO)/World Congress on Gastrointestinal Cancer, Barcelona. Eur. J. Cancer 2017, 86, 305-317.

69. Ebi, H.; Bando, H.; Taniguchi, H.; Sunakawa, Y.; Okugawa, Y.; Hatanaka, Y.; Hosoda, W.; Kumamoto, K.; Nakatani, K.; Yamazaki, K. Japanese Society of Medical Oncology Clinical Guidelines: Molecular Testing for Colorectal Cancer Treatment, 4 th edition. Cancer Sci. 2020, 111, 3962-3969. [CrossRef]

70. García-Foncillas, J.; Alba, E.; Aranda, E.; Díaz-Rubio, E.; López-López, R.; Tabernero, J.; Vivancos, A. Incorporating BEAMing technology as a liquid biopsy into clinical practice for the management of colorectal cancer patients: An expert taskforce review. Ann. Oncol. 2017, 28, 2943-2949. [CrossRef]

71. Misale, S.; Yaeger, R.; Hobor, S.; Scala, E.; Janakiraman, M.; Liska, D.; Valtorta, E.; Schiavo, R.; Buscarino, M.; Siravegna, G.; et al. Emergence of KRAS mutations and acquired resistance to anti-EGFR therapy in colorectal cancer. Nature 2012, 486, 532-536 [CrossRef] [PubMed]

72. Diaz, L.A., Jr.; Williams, R.T.; Wu, J.; Kinde, I.; Hecht, J.R.; Berlin, J.; Allen, B.; Bozic, I.; Reiter, J.G.; Nowak, M.A.; et al. The molecular evolution of acquired resistance to targeted EGFR blockade in colorectal cancers. Nature 2012, 486, 537-540. [CrossRef]

73. Siravegna, G.; Mussolin, B.; Buscarino, M.; Corti, G.; Cassingena, A.; Crisafulli, G.; Ponzetti, A.; Cremolini, C.; Amatu, A.; Lauricella, C.; et al. Clonal evolution and resistance to EGFR blockade in the blood of colorectal cancer patients. Nat. Med. 2015, 21, 795-801. [CrossRef]

74. Cremolini, C.; Rossini, D.; Dell'Aquila, E.; Lonardi, S.; Conca, E.; Del Re, M.; Busico, A.; Pietrantonio, F.; Danesi, R.; Aprile, G.; et al. Rechallenge for Patients with RAS and BRAF Wild-Type Metastatic Colorectal Cancer with Acquired Resistance to First-line Cetuximab and Irinotecan: A Phase 2 Single-Arm Clinical Trial. JAMA Oncol. 2019, 5, 343-350. [CrossRef] [PubMed]

75. Martinelli, E.; Martini, G.; Famiglietti, V.; Troiani, T.; Napolitano, S.; Pietrantonio, F.; Ciardiello, D.; Terminiello, M.; Borrelli, C.; Vitiello, P.P.; et al. Cetuximab rechallenge plus avelumab in pretreated patients with RAS wild-type metastatic colorectal cancer: The phase 2 single-arm clinical CAVE trial. JAMA Oncol. 2021, 7, 1529-1535. [CrossRef]

76. Ma, C.X.; Bose, R.; Gao, F.; Freedman, R.A.; Telli, M.L.; Kimmick, G.; Winer, E.; Naughton, M.; Goetz, M.P.; Russell, C.; et al. Neratinib Efficacy and Circulating Tumor DNA Detection of HER2 Mutations in HER2 Nonamplified Metastatic Breast Cancer. Clin. Cancer Res. 2017, 23, 5687-5695. [CrossRef]

77. Turner, N.C.; Kingston, B.; Kilburn, L.S.; Kernaghan, S.; Wardley, A.M.; Macpherson, I.R.; Baird, R.D.; Roylance, R.; Stephens, P.; Oikonomidou, O.; et al. Circulating tumour DNA analysis to direct therapy in advanced breast cancer (plasmaMATCH): A multicentre, multicohort, phase 2a, platform trial. Lancet Oncol. 2020, 21, 1296-1308. [CrossRef]

78. Aggarwal, C.; Thompson, J.C.; Chien, A.L.; Quinn, K.J.; Hwang, W.T.; Black, T.A.; Yee, S.S.; Christensen, T.E.; LaRiviere, M.J.; Silva, B.A.; et al. Baseline plasma tumor mutation burden predicts response to pembrolizumab-based therapy in patients with metastatic non-small cell lung cancer. Clin. Cancer Res. 2020, 26, 2354-2361. [CrossRef]

79. Gandara, D.R.; Paul, S.M.; Kowanetz, M.; Schleifman, E.; Zou, W.; Li, Y.; Rittmeyer, A.; Fehrenbacher, L.; Otto, G.; Malboeuf, C.; et al. Blood-based tumor mutational burden as a predictor of clinical benefit in non-small-cell lung cancer patients treated with atezolizumab. Nat. Med. 2018, 24, 1441-1448. [CrossRef] [PubMed]

80. Si, H.; Kuziora, M.; Quinn, K.J.; Helman, E.; Ye, J.; Liu, F.; Scheuring, U.; Peters, S.; Rizvi, N.A.; Brohawn, P.Z.; et al. A blood-based assay for assessment of tumor mutational burden in first-line metastatic NSCLC treatment: Results from the MYSTIC study. Clin. Cancer Res. 2021, 27, 1631-1640. [CrossRef]

81. Fribbens, C.; O'Leary, B.; Kilburn, L.; Hrebien, S.; Garcia-Murillas, I.; Beaney, M.; Cristofanilli, M.; Andre, F.; Loi, S.; Loibl, S.; et al. Plasma ESR1 Mutations and the Treatment of Estrogen Receptor-Positive Advanced Breast Cancer. J. Clin. Oncol. 2016, 34, 2961-2968. [CrossRef]

82. Turner, N.C.; Swift, C.; Kilburn, L.; Fribbens, C.; Beaney, M.; Garcia-Murillas, I.; Budzar, A.U.; Robertson, J.F.R.; Gradishar, W.; Piccart, M.; et al. ESR1 mutations and overall survival on fulvestrant versus exemestane in advanced hormone receptor-positive breast cancer: A combined analysis of the phase III SoFEA and EFECT trials. Clin. Cancer Res. 2020, 26, 5172-5177. [CrossRef] [PubMed]

83. Vidula, N.; Rich, T.A.; Sartor, O.; Yen, J.; Hardin, A.; Nance, T.; Lilly, M.B.; Nezami, M.A.; Patel, S.P.; Carneiro, B.A.; et al. Routine plasma-based genotyping to comprehensively detect germline, somatic, and reversion BRCA mutations among patients with advanced solid tumors. Clin. Cancer Res. 2020, 26, 2546-2555. [CrossRef]

84. Goyal, L.; Saha, S.K.; Liu, L.Y.; Siravegna, G.; Leshchiner, I.; Ahronian, L.G.; Lennerz, J.K.; Vu, P.; Deshpande, V.; Kambadakone, A.; et al. Polyclonal secondary fgfr2 mutations drive acquired resistance to FGFR inhibition in patients with FGFR2 fusion-positive cholangiocarcinoma. Cancer Discov. 2017, 7, 252-263. [CrossRef] 
85. Rothwell, D.G.; Ayub, M.; Cook, N.; Thistlethwaite, F.; Carter, L.; Dean, E.; Smith, N.; Villa, S.; Dransfield, J.; Clipson, A.; et al. Utility of ctDNA to support patient selection for early phase clinical trials: The TARGET study. Nat. Med. 2019, 25, 738-743. [CrossRef]

86. Nakamura, Y.; Taniguchi, H.; Ikeda, M.; Bando, H.; Kato, K.; Morizane, C.; Esaki, T.; Komatsu, Y.; Kawamoto, Y.; Takahashi, N.; et al. Clinical utility of circulating tumor DNA sequencing in advanced gastrointestinal cancer: SCRUM-Japan GI-SCREEN and GOZILA studies. Nat. Med. 2020, 26, 1859-1864. [CrossRef]

87. Bettegowda, C.; Sausen, M.; Leary, R.J.; Kinde, I.; Wang, Y.; Agrawal, N.; Bartlett, B.R.; Wang, H.; Luber, B.; Alani, R.M.; et al. Detection of circulating tumor DNA in early- and late-stage human malignancies. Sci. Transl. Med. 2014, 6, 224ra24. [CrossRef] [PubMed]

88. Zill, O.A.; Banks, K.C.; Fairclough, S.R.; Mortimer, S.A.; Vowles, J.V.; Mokhtari, R.; Gandara, D.R.; Mack, P.C.; Odegaard, J.I.; Nagy, R.J.; et al. the landscape of actionable genomic alterations in cell-free circulating tumor DNA from 21,807 advanced cancer patients. Clin Cancer Res. 2018, 24, 3528-3538. [CrossRef] [PubMed]

89. Martínez-Ricarte, F.; Mayor, R.; Martínez-Sáez, E.; Rubio-Pérez, C.; Pineda, E.; Cordero, E.; Cicuéndez, M.; Poca, M.A.; LópezBigas, N.; y Cajal, S.R.; et al. Molecular diagnosis of diffuse gliomas through sequencing of cell-free circulating tumor DNA from cerebrospinal fluid. Clin. Cancer Res. 2018, 24, 2812-2819. [CrossRef]

90. Chan, H.T.; Chin, Y.M.; Nakamura, Y.; Low, S.K. Clonal hematopoiesis in liquid biopsy: From biological noise to valuable clinical implications. Cancers 2020, 12, 2277. [CrossRef]

91. Razavi, P.; Li, B.T.; Brown, D.N.; Jung, B.; Hubbell, E.; Shen, R.; Abida, W.; Juluru , K.; de Bruijn, I.; Hou, C.; et al. High-intensity sequencing reveals the sources of plasma circulating cell-free DNA variants. Nat. Med. 2019, 25, 1928-1937. [CrossRef]

92. Schouten, R.D.; Vessies, D.C.L.; Bosch, L.J.W.; Barlo, N.P.; van Lindert, A.S.; Cillessen, S.A.; van den Broek, D.; van den Heuvel, M.M.; Monkhorst, K. Clinical utility of plasma-based comprehensive molecular profiling in advanced non-small-cell lung cancer. JCO Precis. Oncol. 2021, 5, 1112-1121. [CrossRef]

93. Huang, F.; Yang, Y.; Chen, X.; Jiang, H.; Wang, H.; Shen, M.; Yu, Y.; Liu, T.; Pan, B.; Wang, B.; et al. Chemotherapy-associated clonal hematopoiesis mutations should be taken seriously in plasma cell-free DNA KRAS/NRAS/BRAF genotyping for metastatic colorectal cancer. Clin. Biochem. 2021, 92, 46-53. [CrossRef] [PubMed]

94. Jensen, K.; Konnick, E.Q.; Schweizer, M.T.; Sokolova, A.O.; Grivas, P.; Cheng, H.H.; Klemfuss, N.M.; Beightol, M.; Yu, E.Y.; Nelson, P.S.; et al. Association of clonal hematopoiesis in DNA repair genes with prostate cancer plasma cell-free DNA testing interference. JAMA Oncol. 2021, 7, 107-110. [CrossRef]

95. Rose Brannon, A.; Jayakumaran, G.; Diosdado, M.; Patel, J.; Razumova, A.; Hu, Y.; Meng, F.; Haque, M.; Sadowska, J.; Murphy, B.J.; et al. Enhanced specificity of clinical high-sensitivity tumor mutation profiling in cell-free DNA via paired normal sequencing using MSK-ACCESS. Nat. Commun. 2021, 12, 3770. [CrossRef] [PubMed]

96. Adashek, J.J.; Kato, S.; Parulkar, R.; Szeto, C.W.; Sanborn, J.Z.; Vaske, C.J.; Benz, S.C.; Reddy, S.K.; Kurzrock, R. Transcriptomic silencing as a potential mechanism of treatment resistance. JCI Insight 2020, 5, e134824. [CrossRef]

97. Chuang, C.H.; Chen, H.L.; Chang, H.M.; Tsai, Y.C.; Wu, K.L.; Chen, I.H.; Chen, K.C.; Lee, J.Y.; Chang, Y.C.; Chen, C.L.; et al. Systematic review and network meta-analysis of anaplastic lymphoma kinase (ALK) inhibitors for treatment-naïve ALK-positive lung cancer. Cancers 2021, 13, 1966. [CrossRef]

98. Bradford, D.; Larkins, E.; Mushti, S.L.; Rodriguez, L.; Skinner, A.M.; Helms, W.S.; Price, L.S.L.; Zirkelbach, J.F.; Li, Y.; Liu, J.; et al. FDA Approval summary: Selpercatinib for the treatment of lung and thyroid cancers with RET gene mutations or fusions. Clin. Cancer Res. 2021, 27, 2130-2135. [CrossRef] [PubMed]

99. Sailer, V.; Eng, K.W.; Zhang, T.; Bareja, R.; Pisapia, D.J.; Sigaras, A.; Bhinder, B.; Romanel, A.; Wilkes, D.; Sticca, E.; et al. Integrative Molecular Analysis of Patients with Advanced and Metastatic Cancer. JCO Precis. Oncol. 2019, 3, PO.19.00047. [CrossRef]

100. Beaubier, N.; Bontrager, M.; Huether, R.; Igartua, C.; Lau, D.; Tell, R.; Bobe, A.M.; Bush, S.; Chang, A.L.; Hoskinson, D.C.; et al. Integrated genomic profiling expands clinical options for patients with cancer. Nat. Biotechnol. 2019, 37, 1351-1360. [CrossRef]

101. Marchiò, C.; Scaltriti, M.; Ladanyi, M.; Iafrate, A.J.; Bibeau, F.; Dietel, M.; Hechtman, J.F.; Troiani, T.; López-Rios, F.; Douillard, J.Y.; et al. ESMO recommendations on the standard methods to detect NTRK fusions in daily practice and clinical research. Ann. Oncol. 2019, 30, 1417-1427. [CrossRef] [PubMed]

102. Benayed, R.; Offin, M.; Mullaney, K.; Sukhadia, P.; Rios, K.; Desmeules, P.; Ptashkin, R.; Won, H.; Chang, J.; Halpenny, D.; et al. High yield of RNA sequencing for targetable kinase fusions in lung adenocarcinomas with no mitogenic driver alteration detected by DNA sequencing and low tumor mutation burden. Clin. Cancer Res. 2019, 25, 4712-4722. [CrossRef]

103. Herberts, C.; Wyatt, A.W. Technical and biological constraints on ctDNA-based genotyping. Trends Cancer 2021, 7, 995-1009. [CrossRef] [PubMed]

104. Woolston, A.; Khan, K.; Spain, G.; Barber, L.J.; Griffiths, B.; Gonzalez-Exposito, R.; Hornsteiner, L.; Punta, M.; Patil, Y.; Newey, A.; et al. Genomic and transcriptomic determinants of therapy resistance and immune landscape evolution during anti-EGFR treatment in colorectal cancer. Cancer Cell 2019, 36, 35-50. [CrossRef]

105. Soucheray, M.; Capelletti, M.; Pulido, I.; Kuang, Y.; Paweletz, C.P.; Becker, J.H.; Kikuchi, E.; Xu, C.; Patel, T.B.; Al-Shahrour, F.; et al. Intratumoral Heterogeneity in EGFR-Mutant NSCLC Results in Divergent Resistance Mechanisms in Response to EGFR Tyrosine Kinase Inhibition. Cancer Res. 2015, 75, 4372-4383. [CrossRef] [PubMed]

106. Van 't Erve, I.; Greuter, M.J.E.; Bolhuis, K.; Vessies, D.C.L.; Leal, A.; Vink, G.R.; van den Broek, D.; Velculescu, V.E.; Punt, C.J.A.; Meijer, G.A.; et al. Diagnostic Strategies toward Clinical Implementation of Liquid Biopsy RAS/BRAF Circulating Tumor DNA Analyses in Patients with Metastatic Colorectal Cancer. J. Mol. Diagn. 2020, 22, 1430-1437. [CrossRef] 